\title{
Nanometric Deposition of Fluoride Ions on Titanium Alloys and its Influence on In Vitro Bacterial Adhesion and Viability
}

\author{
Alexandre Barboza Lemos ${ }^{a}$ (D), Carlos Nelson Elias ${ }^{b}$ (D), Rogério Rodrigues Bastos ${ }^{a} \mathbb{( D}$, \\ Elizabeth Ferreira Martinez ${ }^{c *}$ (1) \\ ${ }^{a}$ Faculdade São Leopoldo Mandic, Divisão de Implantologia Oral,Campinas, SP, Brasil. \\ ${ }^{b}$ Instituto Militar de Engenharia, Departamento de Ciência dos Materiais, Rio de Janeiro, RJ, Brasil. \\ ${ }^{c}$ Faculdade São Leopoldo Mandic, Divisão de Biologia Celular, Campinas, SP, Brasil.
}

Received: March 25, 2021; Revised: June 29, 2021; Accepted: June 30, 2021

\begin{abstract}
Bacterial colonization plays a key role on the pathogenesis of peri-implantitis and may be influenced by titanium surface topography. The aim of this in vitro study was to evaluate the influence of titanium topography after fluoride ions deposition in the bacterial colonization. Machined (M), double acidetched (DE) and double acid-etched surface with fluoride ions deposition (Nano $\mathrm{F}^{-}$) were analyzed by scanning electron microscopy, contact angle and roughness (Ra). Streptococcus mutans viability was quantified by Live/Dead Baclight bacterial viability kit. The mean Ra/contact angle values were $0.20 \mu \mathrm{m} / 69.13^{\circ}, 0.53 \mu \mathrm{m} / 92.82^{\circ}$ and $0.56 \mu \mathrm{m} / 94.33^{\circ}$ for $\mathrm{M}, \mathrm{DE}$ and Nano $\mathrm{F}^{-}$, respectively. M surface presented significantly lower live bacterial counts when compared to the Nano $\mathrm{F}^{-}$surface $(\mathrm{p}=0.007)$. The dead bacteria count was higher on the Nano $\mathrm{F}^{-}$surface $(\mathrm{p}=0.001)$ than on the $\mathrm{M}$ and $\mathrm{DE}$ surfaces. Crystalline deposition of fluoride ions (Nano $\mathrm{F}^{-}$) promoted an increase in dead bacteria on the tested titanium surface.
\end{abstract}

Keywords: Peri-implantitis, implant surface, fluoride, bacterial adhesion, biofilm.

\section{Introduction}

The growing use of osseointegrated titanium implants to replace lost teeth secondary to periodontal disease and periimplant infections has led to the development of new types of surface treatment, not only to accelerate osseointegration but also aiming a reducing bacterial colonization at the implant surface ${ }^{1,2}$. Bacterial adhesion and colonization play a key role on the pathogenesis of peri-implant inflammation, which is regarded as one of the main causes of implant loss ${ }^{3}$.

The physicochemical characteristics of the titanium surfaces therefore significantly influence bacterial adhesion ${ }^{4,5}$. Changes to such characteristics may have a significant impact on the biofilm adhesion to this surface, since bacterial adhesion is dependent on surface roughness, chemical composition and surface energy ${ }^{6,7}$.

The incorporation of ions onto the surface of the implants aims to optimize osteoblast adhesion, as well as to produce an anti-bacterial surface ${ }^{8}$, similarly to what has been done with silver ions in a number of studies ${ }^{8-12}$. The antibacterial action of silver is not fully understood, though it is suggested that silver nanoparticles can penetrate the bacterial cell wall and act on the respiratory chain causing cell death ${ }^{11,12}$.

Other chemical modifications have been suggested, such as zirconia ${ }^{13,14}$, nitride ${ }^{15,16}$, magnesium ${ }^{17}$, with strontium, cobalt and fluorine ${ }^{18,19}$ and antimicrobials such as metronidazole ${ }^{20}$ to reduce bacterial adhesion or viability. Besides these, fluoride ion deposition has been proposed due to its anti- bacterial activity ${ }^{21,22}$. One of the major mechanisms of action of fluoride is acidification of the bacterial cell cytoplasm, reducing bacterial tolerance to their own acids, leading to cell death, just as fluoride has been widely used in dentistry with great effectiveness as an anti-cariogenic agent. The ability of fluoride to act as a transmembrane proton conductor is deleterious to many acid-sensitive cytoplasmic enzyme systems, as related to oral streptococci ${ }^{23}$.

Based on the influence of peri-implant infections in the long-term success of osseointegrated implants, this study aimed to evaluate bacterial adhesion and viability on crystalline deposition of fluoride ions deposition surfaces correlating them with the physical and topographical characteristics.

\section{Materials and Methods}

\subsection{Characterization of titanium surfaces}

Commercially pure titanium (grade 4) discs measuring $6 \mathrm{~mm}$ in diameter and $2 \mathrm{~mm}$ in thickness were provided by Conexão Sistemas de Prótese (Arujá, SP, Brazil) and divided into three groups, as previously described by Elias et al. ${ }^{24}$ :

a) Machined (M): without any surface treatment $(\mathrm{n}=14)$;

b) Double-etched (DE): treated in acidic solutions containing $\mathrm{HCl}+\mathrm{H}_{2} \mathrm{SO}_{4}$ at $50^{\circ} \mathrm{C}$ for $25 \mathrm{~min}(\mathrm{n}=14)$. After etching, the specimens were rinsed thoroughly with distilled water; 
c) Deposition of fluoride ions (Nano $\left.\mathrm{F}^{-}\right)$: treated in acid solution as previously described (DE), followed by fluoride ion modification by immersion in $\mathrm{NaF}$ solution for $1 \mathrm{~h}$ at room temperature $(\mathrm{n}=14)$.

For the analysis of surface characterization, the ultrastructural morphology (SEM), roughness $(\mathrm{Ra})$ and contact angle measurements of the different surfaces were determined. The values of semiquantitative chemical compositions (\%) were obtained by fluorescence X-ray diffraction in a previous study ${ }^{24}$, with only $0.9 \%$ fluoride ion observed on the Nano $\mathrm{F}^{-}$surface.

The ultrastructural morphology of the samples was evaluated on a field-emission guns scanning electron microscope (Quanta FEG 250; FEI Company, Eindhoven, the Netherlands). Three specimens from each surface were mounted directly on stubs and imaged at $1000 \mathrm{X}$ and $20000 \mathrm{X}$ magnification.

For the surface roughness ( $\mathrm{Ra}$ ) analysis, 4 specimens of each of the three surfaces was evaluated by using a stylus instrument (profilometer, Mitutoyo Surftest SJ-200, Japan). Four linear measurements were performed on each sample according to DIN ISO 1302 standards and the arithmetic average of the roughness profile $(\mathrm{Ra})$ was calculated for each sample.

For the contact angle measurements (goniometer, First Ten Angstroms, FTA100), $1 \mu \mathrm{L}$ of deionized water was dispersed on the sample surface and the internal angle between the drop of water and the titanium surface was calculated. Two measurements were performed on each sample, using the same 4 disks used for roughness measurement and the arithmetic average of each was calculated. For angles lower than $90^{\circ}$, the surface was considered hydrophilic and for angles greater than $90^{\circ}$, hydrophobic ${ }^{25}$.

\subsection{Bacterial viability assay}

An ATCC standard strain (American Type Culture Collection, USA) of Streptococcus mutans (ATCC 25175) was used. This microorganism was selected because it represents $45 \%$ of the bacterial species in the initial biofilm ${ }^{25,26}$. Cultures from a single colony were cultivated in sterile brain heart infusion broth (BHI; Himedia, Indian) at $37{ }^{\circ} \mathrm{C}$ for $18 \mathrm{~h}$, under microaerophilic conditions. After, the bacterial suspension was centrifuged at $2200 \mathrm{rpm}$ at $18^{\circ} \mathrm{C}$ for $5 \mathrm{~min}$ and the optical density of the suspensions was adjusted to 1.0 at $540 \mathrm{~nm}$, which corresponded to a microbial concentration of $12 \times 10^{8}$ cells $/ \mathrm{ml}$.

The bacteria were cultured on each sample ( $\mathrm{n}=3$ for each treatment) and incubated for $4 \mathrm{~h}$ at $37^{\circ} \mathrm{C}$ under microaerophilic conditions. After this incubation time, the samples were gently rinsed with sterile saline solution $(0.9 \%)$ and for the viability and adhesion test, the BacLight Live/Dead kit (Molecular Probe, OR, USA) was used as described in a previous study 5 .

Samples were examined under a fluorescence microscope (Zeiss, Germany) at 400X magnification. The excitation/ emission wavelengths of SYTO9 and propidium iodide were 480/500 $\mathrm{nm}$ and 490/635 nm, respectively. The live/dead stain was prepared by diluting $1 \mu \mathrm{l}$ of staining component A (SYTO 9) and $1 \mu \mathrm{l}$ of staining component B (propidium iodide) in $3 \mathrm{ml}$ of distilled water. Seventy $\mu \mathrm{l}$ of the reagent mixture were dispensed to each surface, and specimens were incubated in darkness for $15 \mathrm{~min}$ at room temperature. A glass slide covered with component $\mathrm{C}$ (mounting oil) was positioned on the surface and stored in the dark at $4{ }^{\circ} \mathrm{C}$ until further processing.

Six images were captured from randomly selected sites for each analyzed surface. To determine the viability of the adhered bacterial species for each type of surface treatment, the green and red zones were separately measured, representing live and dead bacterial cells, respectively. The bacterial cell count for each dye in relation to the total area, was performed on the ImageJ software (National Institute of Health, NIH, USA) and presented in arbitrary units (AU) and percentage for each surface. All images had a standard area of $97 \mu \mathrm{m}^{2}$, totaling $582 \mu \mathrm{m}^{2}$ for the 6 images analyzed. The experiments were carried out in triplicates for each surface.

\subsection{Analysis of bacterial adhesion by SEM}

S. mutans was seeded onto three samples of each different surface under the same aforementioned conditions and fixed with $2.5 \%$ glutaraldehyde solution in $0.1 \mathrm{M}$ cacodylate buffer $\left(\mathrm{pH} \mathrm{7.2)}\right.$ for $1 \mathrm{~h}$ at $4{ }^{\circ} \mathrm{C}$. The disks were then rinsed in the same buffer $(0.05 \mathrm{M})$, post-fixed in $2 \%$ osmium tetroxide for $1 \mathrm{~h}$, followed by dehydration through a graded series of ethanol. The samples were mounted on stubs and placed on a sputter coater (Leica EM ACE600, Wetzlar, Germany) to receive an $8 \mathrm{~nm}$ platinum coverage prior to scanning electron microscopy analysis (Quanta FEG 250; FEI Company, Eindhoven, the Netherlands).

\subsection{Statistical analysis}

The statistical analyses were conducted at a 5\% significance level on SPSS 20 (SPSS Inc., Chicago, IL, USA). Analysis between groups was performed using One-way (ANOVA), followed by the Tukey test. The correlation between the percentage live and dead bacteria as well as total bacterial cell counts was performed using the Pearson's test.

\section{Results and Discussion}

Despite the high predictability of treatment with osseointegrated implants, biofilm formation on implant surfaces plays an important role on the progression of peri-implant infections ${ }^{1,2}$. Thus, the present study aimed to evaluate bacterial adhesion and viability onto a double acid-etched surface with fluoride ions deposition (Nano $\mathrm{F}^{-}$), compared to double acid-etched (DE) and machined (M) surfaces, correlating the findings with the physicochemical properties of these surfaces.

\subsection{Characteristics of surface topography}

The ultrastrucutral morphology of the surfaces is represented in Figure 1 by scanning electron micrographs. The $\mathrm{M}$ samples showed unidirectional grooves (Figure 1A, B), unlike the surfaces DE and Nano F-, which presented uniform roughness, with different sizes and sharp edges (Figure 1C, D, E, F). Nonetheless, the Nano $\mathrm{F}^{-}$surface showed a more uniform pattern and lower range of roughness than the DE, with approximate values ranging from 400 to $500 \mathrm{~nm}$, being therefore regarded as nanometric (Figure 1E, F). Additionally, 

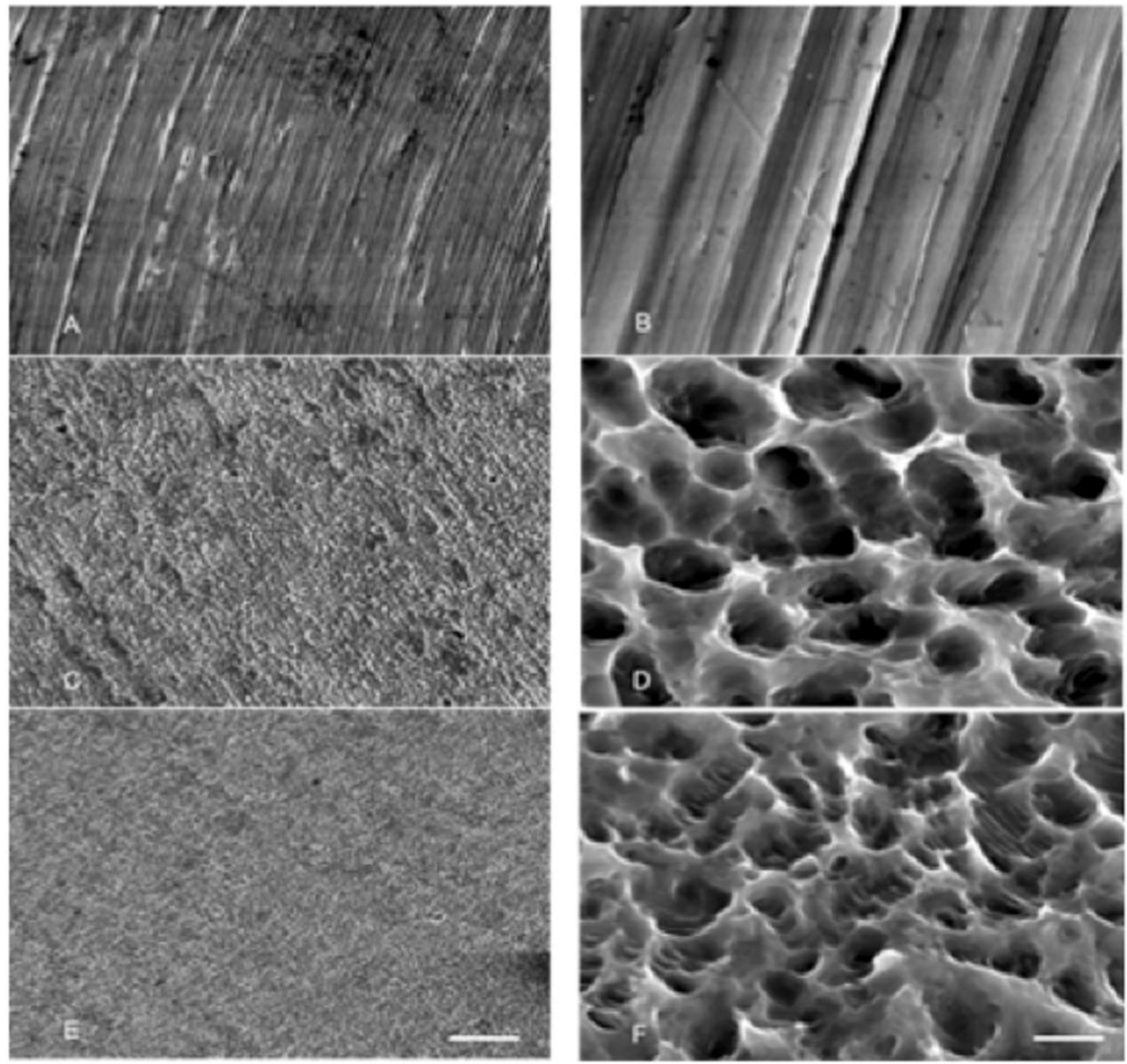

Figure 1. Scanning electron microscope micrographs of M (A, B), DE (C, D) and Nano F- surfaces (E, F). Scale bar = $100 \mu \mathrm{m}(\mathrm{A}, \mathrm{C}, \mathrm{E})$ and $5 \mu \mathrm{m}(\mathrm{B}, \mathrm{D}, \mathrm{F}) . \mathrm{M}=$ machined, $\mathrm{DE}=$ double acid-etched, Nano $\mathrm{F}^{-}=\mathrm{DE}$ with deposition of fluoride ions.

at a high magnification (Figure 1F), it was evident the presence of nano roughness inside de microcavities, indicating the immersion in a solution containing fluoride ions.

The physicochemical characteristics of the samples were assessed to evaluate the influence of roughness and contact angle on bacterial adhesion and viability. The results showed that surface $\mathrm{M}$ presented lower values of roughness $(0.20 \pm 0.02 \mu \mathrm{m})$ in relation to surface $\mathrm{DE}(0.53 \pm 0.07 \mu \mathrm{m})$ and Nano $F^{-}(0.56 \pm 0.04 \mu \mathrm{m})(\mathrm{p}<0.05)$. However, the rough surfaces (DE and Nano $\mathrm{F}^{-}$) were not significantly different $(\mathrm{p}=0.49)$ from each other. Similarly, the surface $\mathrm{M}$ had lower contact angle $\left(69.13 \pm 2.43^{\circ}\right)$ than DE $\left(92.82 \pm 5.33^{\circ}\right)$ and Nano $F^{-}\left(94.33 \pm 4.55^{\circ}\right)$, and the latter two did not differ significantly from each other $(p=0.61)$.

Despite the roughness values of $\mathrm{DE}$ and $\mathrm{Nano}^{-}$surfaces were higher than the $\mathrm{M}$ surface, according Wenneberg and Albrektsson titanium surface classification ${ }^{27}$, the treated surfaces evaluated presented minimal roughness. A number of studies indicate that the greater the roughness, the greater the bacterial adhesion ${ }^{28,29}$; however, Busscher et al..$^{30}$ stated that surfaces with roughness above $0.2 \mu \mathrm{m}$ could be less prone to bacterial adhesion provided that modifications were made to the surface energy or chemical composition of this surface.

Contact angle has been used to quantify surface free energy, where angles lower than $90^{\circ}$ are considered hydrophilic, while surfaces with angles greater than $90^{\circ}$ are regarded as hydrophobic and denote low wettability ${ }^{25}$. In the present study, the M surface was therefore considered hydrophilic, whereas the surfaces with roughness (DE and Nano $\mathrm{F}^{-}$), were considered hydrophobic. Such wettability values combined with surface topography are crucial for the selectivity and quantity of bacterial adhesion ${ }^{28,31}$.

\subsection{Bacterial viability and adhesion assay}

S. mutans was used because, according to the methodology found in two previous studies ${ }^{32,33}$ because 
this bacterial specie is an early colonizer of the surfaces of different biomaterials, including titanium ${ }^{25,34,35}$, and such early colonization provides favorable conditions for the apposition of further pathogens, including those related to periodontal and peri-implant disease $\mathrm{e}^{3,13,36}$. In addition, $S$. mutans is the most prevalent species in biofilm ${ }^{25,26}$. Therefore, reduction in the number of early colonizing bacteria to a given surface is an important antibacterial strategy for implant maintenance ${ }^{33,37}$.

The representative data of the bacterial count (AU) and percentage of the areas with live and dead strains for each surface are presented in Table 1 and the respective images in Figure 2.

The results showed that the live bacteria adhesion was significantly influenced by surface treatments $(p<0.05)$. In the $\mathrm{M}$ surface, the live bacteria count was significantly lower in relation to that verified on the Nano $\mathrm{F}^{-}$surface. On the DE surface, bacteria count did not differ significantly from the other surfaces. Similarly, the dead bacteria count was affected by the surface treatment and was significantly higher on the Nano F-surface, though no difference was observed between the DE and M surfaces $(p=0.001)$.

The Pearson's tests indicated a positive and moderate correlation between the percentage of area of live bacteria and bacterial count $\left(\mathrm{p}=0.002 ; \mathrm{r}^{2}=0.538\right)$. For dead bacteria, a positive and strong correlation $\left(\mathrm{p}=0.001 ; \mathrm{r}^{2}=0.96\right)$ was observed between the percentage of area colonized by the microorganisms and their total count (Figure 3).

In order to validate the quantitative data of bacterial count on different surfaces, Figure 4 illustrates the presence of bacteria in the deepest aspects of the rough topography on the treated surfaces, inside the microcavities.

Table 1. Average (SD) values of the bacterial count (AU) and of the percentage of area (\%) including live and dead bacteria, according to surface treatment. $\mathrm{M}=$ machined, $\mathrm{DE}=$ double acid-etched, Nano $\mathrm{F}^{-}=\mathrm{DE}$ with deposition of fluoride ions. Means followed by different letters within the same column denote a significant difference.

\begin{tabular}{|c|c|c|c|c|}
\hline \multirow{2}{*}{ Surfaces } & \multicolumn{2}{|c|}{ Live bacteria } & \multicolumn{2}{|c|}{ Dead bacteria } \\
\hline & Count (AU) & Area $(\%)$ & Count (AU) & Area $(\%)$ \\
\hline $\mathrm{M}$ & $3855(965) b$ & $8.34(2.48) b$ & $317(83) \mathrm{b}$ & $0.68(0.18) \mathrm{b}$ \\
\hline $\mathrm{DE}$ & $4808(666) \mathrm{ab}$ & $12.79(1.55) \mathrm{ab}$ & $386(76) b$ & $0.75(0.21) \mathrm{b}$ \\
\hline Nano $F^{-}$ & $5564(1529) \mathrm{a}$ & $11.76(3.95) \mathrm{a}$ & $646(167) \mathrm{a}$ & $1.95(0.70) \mathrm{a}$ \\
\hline ANOVA & $\mathrm{p}=0.007$ & $\mathrm{p}=0.004$ & $\mathrm{p}=0.001$ & $\mathrm{p}=0.001$ \\
\hline
\end{tabular}

SYTO9
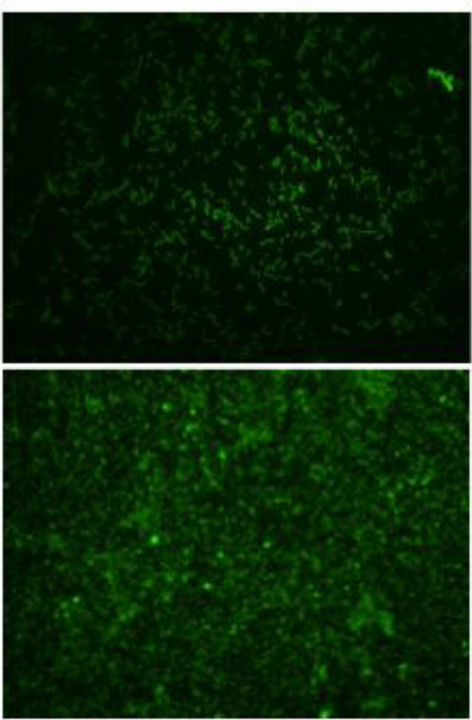

DE

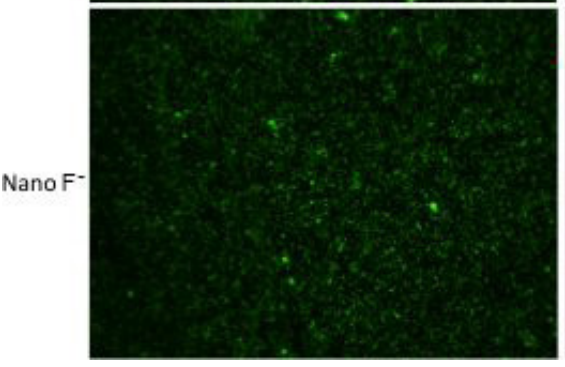

Propidium lodide
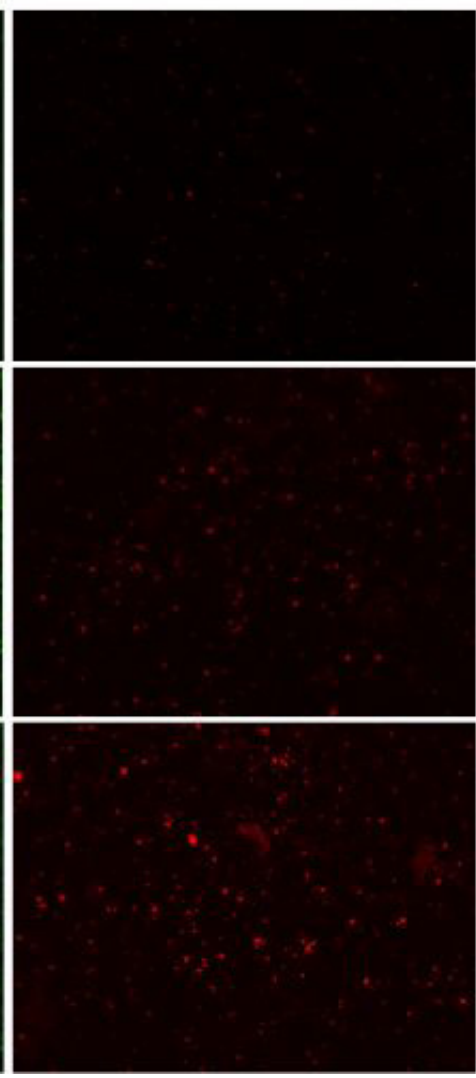

Merged
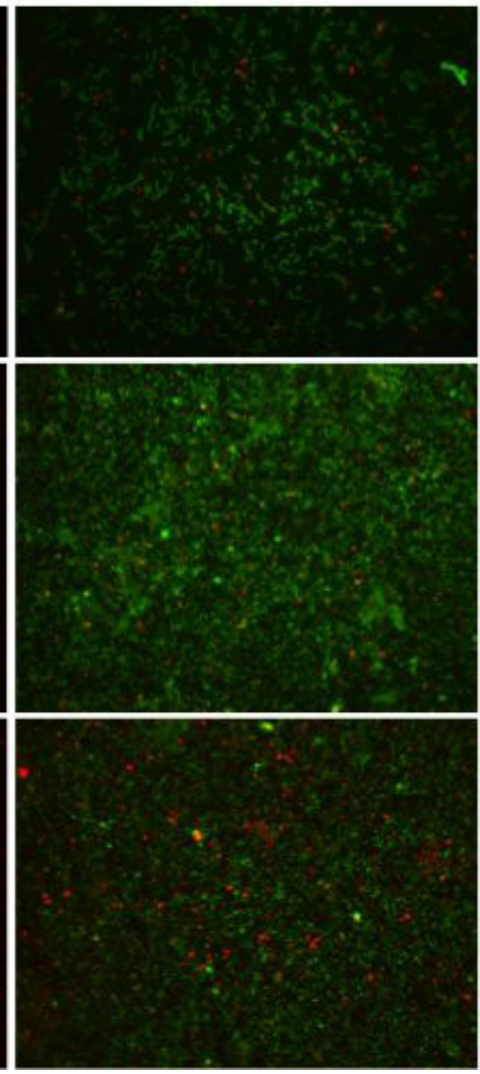

Figure 2. S. mutans fluorescence microscopy micrographs on M (A), DE (B) and Nano F- (C) surfaces. SYTO9 (green) represented live bacteria; Propidium iodine (red) labeled dead bacteria and Merged (green + red) stained live and dead bacteria. Magnification 100X. 
Hydrophobic bacteria colonize hydrophobic surfaces better and the same relationship is observed for hydrophilic bacteria and surfaces ${ }^{30}$. In the present study, $S$. mutans was used, which is considered a hydrophobic microorganism ${ }^{38,39}$. Therefore, a higher bacterial adhesion was expected on rough surfaces, which was indeed observed a smaller area of the hydrophilic polished surface was colonized when compared to the hydrophobic surfaces evaluated in this study, which may be related to the hydrophobic characteristics of the bacterial species.

Additionally, a positive correlation was also observed between roughness and contact angle when comparing machined and rough surfaces. It was expected, however, that rough surfaces would have shown lower contact angles aiming at a greater contact surface with body fluids and with plasma proteins ${ }^{40}$. In the present study, this relationship was not observed, which suggested the possibility of air bubbles being trapped inside the pores of the rough surfaces, preventing water penetration, thus altering the wettability angle.

An increase in the total number of bacterial colonies adhered to the roughest surfaces (DE and Nano $\mathrm{F}^{-}$) was observed when we compared to the machined surface (M), which was statistically significant $(\mathrm{p}=0.004)$, similar to Rodriguez y Baena et al. ${ }^{41}$ and Badihi Haulisch et al. ${ }^{42}$,

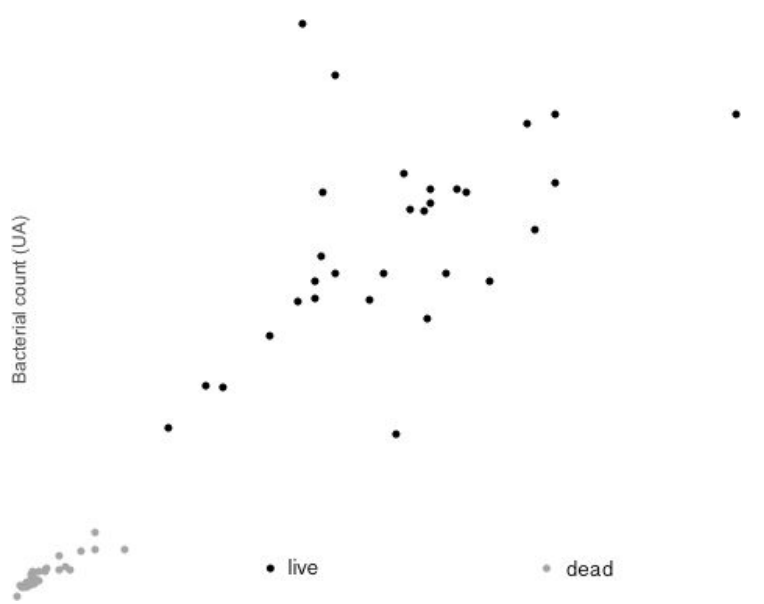

Figure 3. Scatter diagram of the percentage of area colonized by viable and non-viable bacteria as a function of bacterial counts on all surfaces. however, demonstrated that rough surfaces presented lower colony counts. The results obtained by these authors may be associated to a short period of incubation $(2 \mathrm{~h})$ of the samples. In our study, however, no significant difference was detected between the two rough surfaces investigated $(p=0.06)$, due probably to their roughness profiles being statistically similar.

One may therefore infer that rough surfaces are more difficult to decontaminate once colonized ${ }^{43}$. As observed in the present study using SEM, bacterial cells were housed deep inside the roughness pits, making it difficult to remove them and confirming the findings of a higher total number of mechanically retained bacteria into the DE and Nano $\mathrm{F}^{-}$ surfaces $^{29}$. The presence of roughness, however, is associated to higher levels of osseointegration than machined surfaces ${ }^{17}$ which conversely reduces the risk of early bone loss and future bacterial colonization of the implant surface ${ }^{44}$.

Another factor that may affect bacterial colonization is the type of surface treatment. In the present study, DE surfaces were tested, which have been described to cause less bacterial

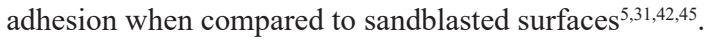

Moreover, different chemical changes to the titanium surface by addition of a variety of ions have been described to favor osseointegration, also aiming at lower bacterial colonization ${ }^{45}$. Silver ions have been used in several studies on titanium surface treatments ${ }^{8-12}$. Despite the antimicrobial effectiveness of silver ions, at high concentrations, they may adversely affect host cell viability. Furthermore, anti-adhesive surfaces may also interfere with host cell adhesion and, consequently, implant integration with surrounding tissues ${ }^{46}$.

In the present study, the surface was modified through crystalline deposition of fluoride ions, creating nanometric roughness and altering the chemical composition of the surface. Fluoride has also been reported to increase the bond strength between titanium apatite coatings ${ }^{47}$ as well as the antimicrobial activity, inducing cytoplasmic acidification and consequently, bacterial death ${ }^{19,21,22}$

Despite the antibacterial effects of fluoride ions are well described, there is currently a renewed interest in creating an implant biocompatible surface presenting an antibacterial effect. In the present study, a higher number of non-viable bacteria on the Nano $\mathrm{F}^{-}$surface was observed than on the $\mathrm{M}$ and DE surfaces. As the DE and Nano $\mathrm{F}^{-}$surfaces were not significantly different with regards to surface roughness and wettability, and the only aspect that differs between them
$\mathrm{M}$

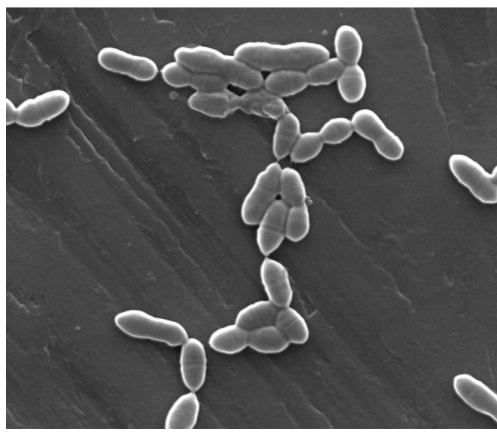

$\mathrm{DE}$

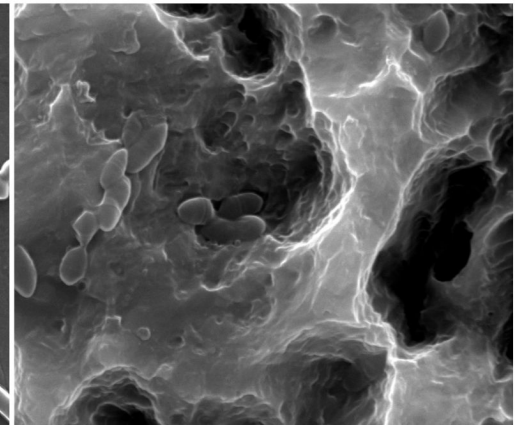

Nano F-

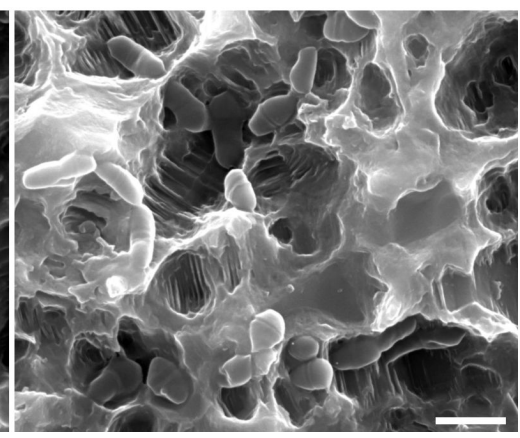

Figure 4. Scanning electron microscopy of the bacteria on the different analyzed surfaces $\mathrm{M}(\mathrm{A}), \mathrm{DE}(\mathrm{B})$ and Nano $\mathrm{F}^{-}(\mathrm{C})$. Bar $=1 \mu \mathrm{m}$. 
was their chemical composition, namely fluoride, it can be inferred that such ion had an important impact on bacterial viability, a fact corroborated by Yoshinari et al. ${ }^{45}$.

\section{Conclusions}

The results described herein show that the physicochemical characteristics of the implant surface, including roughness and chemical composition, influence bacterial colonization and viability. The deposition of crystalline fluoride ions (Nano $\mathrm{F}^{-}$) promoted an increase in dead bacteria on the tested titanium surface.

\section{Acknowledgement}

The authors wish to thank Gilca Saba for her excellent technical expertise and assistance.

\section{References}

1. Caous JS, Lövenklev M, Fäldt J, Langton M. Adhesion of Streptococcus mitis and Actinomyces oris in co-culture to machined and anodized titanium surfaces as affected by atmosphere and pH. BMC Oral Health. 2013;13(1):4

2. Kligman S, Ren Z, Chung CH, Perillo MA, Chang YC, Koo $\mathrm{H}$, et al. The impact of dental implant surface modifications on osseointegration and biofilm formation. J Clin Med. 2021;10(8):1641.

3. Liu J, Liu J, Attarilar S, Wang C, Tamaddon M, Yang C, et al. Nano-modified titanium implant materials: a way toward improved antibacterial properties. Front Bioeng Biotechnol. 2020;8:576969.

4. Subramani K, Jung RE, Molenberg A, Hammerle CH. Biofilm on dental implants: a review of the literature. Int J Oral Maxillofac Implants. 2009;24(4):616-26

5. Bürgers R, Gerlach T, Hahnel S, Schwarz F, Handel G, Gosau M. In vivo and in vitro biofilm formation on two different titanium implant surfaces. Clin Oral Implants Res. 2010;21(2):156-64.

6. Badihi Haulisch L, Sela MN, Steinberg D, Rosen G, Kohavi D. The adhesion of oral bacteria to modified titanium surface: role of plasma proteins and electrostatic forces. Clin Oral Implants Res. 2013;24:49-56.

7. Chang Y-Y, Huang H-L, Lai C-H, Hsu J-T, Shieh T-M, Wu AY$\mathrm{J}$, et al. Analyses of antibacterial activity and cell compatibility of titanium coated with a Zr-C-N film. PLoS One. 2013;8(2):e56771.

8. Yin IX, Zhang J, Zhao IS, Mei ML, Li Q, Chu CH. The antibacterial mechanism of silver nanoparticles and its application in dentistry. Int J Nanomedicine. 2020;2020:2555-62. http:// dx.doi.org/10.2147/IJN.S246764.

9. Choi SH, Jang YS, Jang JH, Bae TS, Lee SJ, Lee MH. Enhanced antibacterial activity of titanium by surface modification with polydopamine and silver for dental implant application. J Appl Biomater Funct Mater. 2019;17(3)

10. Gupta K, Singh RP, Pandey A, Pandey A. Photocatalytic antibacterial performance of $\mathrm{TiO}_{2}$ and $\mathrm{Ag}$-doped $\mathrm{TiO}_{2}$ against S. aureus, P. aeruginosa and E. coli. Beilstein J Nanotechnol. 2013;4:345-51

11. Yeniyol S, He Z, Yüksel B, Boylan RJ, Ürgen M, Özdemir $\mathrm{T}$, et al. Antibacterial activity of As-annealed $\mathrm{TiO}_{2}$ Nanotubes doped with Ag nanoparticles against aeriodontal pathogens. Bioinorg Chem Appl. 2014;2014:1-8.

12. Khorrami S, Zarrabi A, Khaleghi M, Danaei M, Mozafari M. Selective cytotoxicity of green synthesized silver nanoparticles against the MCF-7 tumor cell line and their enhanced antioxidant and antimicrobial properties. Int J Nanomedicine. 2018;13:801324.
13. Liu K, Wang G, Guo S, Liu J, Qu W, Liu N, et al. High-potential surface on zirconia ceramics for bacteriostasis and biocompatibility. Colloids Surf B Biointerfaces. 2020;193:111074.

14. Al-Radha ASD, Dymock D, Younes C, O'Sullivan D. Surface properties of titanium and zirconia dental implant materials and their effect on bacterial adhesion. J Dent. 2012;40(2):146-53.

15. Brunello G, Brun P, Gardin C, Ferroni L, Bressan E, Meneghello $\mathrm{R}$, et al. Biocompatibility and antibacterial properties of zirconium nitride coating on titanium abutments: an in vitro study. PLoS One. 2018;13(6):e0199591.

16. Ji MK, Park SW, Lee K, Kang IC, Yun KD, Kim HS, et al. Evaluation of antibacterial activity and osteoblastic-like cell viability of TiN, $\mathrm{ZrN}$ and (Ti1-x Zrx)N coating on titanium. J Adv Prosthodont. 2015;7(2):166-71

17. Zhou W, Yan J, Li Y, Wang L, Jing L, Li M, et al. Based on the synergistic effect of $\mathrm{Mg}^{2+}$ and antibacterial peptides to improve the corrosion resistance, antibacterial ability and osteogenic activity of magnesium-based degradable metals. Biomater Sci. 2021;9(3):807-25

18. Zhao Q, Yi L, Hu A, Jiang L, Hong L, Dong J. Antibacterial and osteogenic activity of a multifunctional microporous coating codoped with $\mathrm{Mg}, \mathrm{Cu}$ and $\mathrm{F}$ on titanium. J Mater Chem B Mater Biol Med. 2019;7(14):2284-99.

19. Zhou J, Li B, Han Y. F-doped $\mathrm{TiO}_{2}$ microporous coating on titanium with enhanced antibacterial and osteogenic activities. Sci Rep. 2018;8(1):17858.

20. Bunetel L, Guérin J, Agnani G, Piel S, Pinsard H, Corbel JC, et al In vitro study of the effect of titanium on Porphyromonas gingivalis in the presence of metronidazole and spiramycin. Biomaterials. 2001;22(22):3067-72.

21. Marquis RE. Antimicrobial actions of fluoride for oral bacteria. Can J Microbiol. 1995;41(11):955-64.

22. Shin DY, Cheon KH, Song EH, Seong YJ, Park JU, Kim HE, et al. Fluorine-ion-releasing injectable alginate nanocomposite hydrogel for enhanced bioactivity and antibacterial property. Int J Biol Macromol. 2019;123:866-77.

23. Phan TN, Nguyen PTM, Abranches J, Marquis RE. Fluoride and organic weak acids as respiration inhibitors of oral streptococci in acidified environments. Oral Microbiol Immunol. 2002;17(2):119-24.

24. Elias CN, Gravina PA, Silva Filho CE, Nascente PA. Preparation of bioactive titanium surfaces via fluoride and fibronectin retention. Int J Biomater. 2012;2012:290179.

25. Größner-Schreiber B, Teichmann J, Hannig M, Dörfer C, Wenderoth DF, Ott SJ. Modified implant surface show different biofilm compositions under in vivo conditions. Clin Oral Implants Res. 2009;20(8):817-26.

26. Wang C, Hou J, van der Mei HC, Busscher HJ, Ren Y. Emergent properties in Streptococcus mutans biofilms are controlled through adhesion force sensing by initial colonizers. MBio. 2019;10(5):e01908-19.

27. Wennerberg A, Albrektsson T. Effects of titanium surface topography on bone integration: a systematic review. Clin Oral Implants Res. 2009;20:172-84.

28. Zheng S, Bawazir M, Dhall A, Kim HE, He L, Heo J, et al. Implication of surface properties, bacterial motility, and hydrodynamic conditions on bacterial surface sensing and their initial adhesion. Front Bioeng Biotechnol. 2021;9:643722.

29. Teughels W, van Assche N, Sliepen I, Quirynen M. Effect of material characteristics and/or surface topography on biofilm development. Clin Oral Implants Res. 2006;17(S2):68-81.

30. Busscher HJ, Weerkamp AH, van der Mei HC, van Pelt AWJ, Jong HP, Arends J. Measuremtents of the surface free energy of bacterial cell surfaces and its relevance for adhesion. Appl Environ Microbiol. 1984;48(5):980-3.

31. Almaguer-Flores A, Olivares-Navarrete R, Wieland M, Ximénez-Fyvie LA, Schwartz Z, Boyan BD. Influence of topography and hidrophilicity on initial oral biofilm formation 
on microtructured titanium surface in vitro. Clin Oral Implants Res. 2012;23(3):301-7.

32. Fürst MM, Salvi GE, Lang NP, Persson GR. Bacterial colonization immediately after installation on oral titanium implants. Clin Oral Implants Res. 2007;18(4):501-8.

33. Ji MK, Park SW, Lee K, Kang IC, Yun KD, Kim HS, et al. Evaluation of antibacterial activity and osteoblastic-like cell viability of TiN, ZrN and (Ti1-x Zrx)N coating on titanium. J Adv Prosthodont. 2015;7(2):166-71.

34. Teughels W, van Assche N, Sliepen I, Quirynen M. Effect of material characteristics and/or surface topography on biofilm development. Clin Oral Implants Res. 2006;17(S2):68-81.

35. Wang C, van der Mei HC, Busscher HJ, Ren Y. Streptococcus mutans adhesion force sensing in multi-species oral biofilms. NPJ Biofilms Microbiomes. 2020;6(1):25.

36. Oda Y, Miura T, Mori G, Sasaki H, Ito T, Yoshinari M, et al. Adhesion of streptococci to titanium and zirconia. PLoS One. 2020;15(6):e0234524.

37. Carniello V, Peterson BW, van der Mei HC, Busscher HJ. Physico-chemistry from initial bacterial adhesion to surfaceprogrammed biofilm growth. Adv Colloid Interface Sci. 2018;261:1-14.

38. McBride BC, Song M, Krasse BO, Olsson J. Biochemical and immunological differences between hydrophobic and hydrophilic strains of Streptococcus mutans. Infect Immun. 1984;44(1):68-75.

39. Weerkamp AH, van der Mei HC, Busscher HJ. The surface free energy of oral streptococci after being coated with saliva and its relation to adhesion in the mouth. J Dent Res. 1985;64(10):1204-10.
40. Junker R, Dimakis A, Thoneick M, Jansen JA. Effects of implant surface coatings and composition on bone integration: a systematic review. Clin Oral Implants Res. 2009;20:185-206.

41. Rodriguez y Baena R, Arciola CR, Selan L, Battaglia R, Imbriani M, Rizzo S, et al. Evaluation of bacterial adhesion on machined titanium, Osseotite ${ }^{\circledR}$ and Nanotite ${ }^{\circledR}$ discs. Int J Artif Organs. 2012;35(10):754-61.

42. Badihi Hauslich L, Sela MN, Steinberg D, Rosen G, Kohavi D. The adhesion of oral bacteria to modified titanium surface: role of plasma proteins and electrostatic forces. Clin Oral Implants Res. 2013;24:49-56.

43. Renvert S, Polyzois I, Claffey N. How do implant surface characteristics influence peri-implant disease? J Clin Periodontol. 2011;38:214-22.

44. De Bruyn H, Christiaens V, Doornewaard R, Jacobsson M, Cosyn J, Jacquet W, et al. Implant surface roughness and patient factors on long-term peri-implant bone loss. Periodontol 2000. 2017;73(1):218-27.

45. Yoshinari M, Oda Y, Kato T, Okuda K, Hirayama A. Influence of surface modifications to titanium on oral bacterial adhesion in vitro. J Biomed Mater Res. 2000;52(2):388-94.

46. Campoccia D, Cangini I, Selan L, Vercellino M, Montanaro L, Visai L, et al. An overview of the methodological approach to the in vitro study of anti-infective biomaterials. Int J Artif Organs. 2012;35(10):800-16.

47. Tredwin CJ, Georgiou G, Kim HW, Knowles JC. Hydroxyapatite, fluor-hydroxyapatite and fluorapatite produced via the sol-gel method: bonding to titanium and scanning electron microscopy. Dent Mater. 2013;29(5):521-9. 